\title{
Remediation Methods of Crude Oil Contaminated Soil
}

\author{
Anum Ali Ahmad ${ }^{1,2}$, Ishaq Muhammad ${ }^{1}$, Tariq Shah ${ }^{1}$, Qudratullah Kalwar², Jianbo Zhang², Zeyi Liang ${ }^{2}$, Du \\ Mei $^{2}$, Zheng Juanshan ${ }^{2}$, Ping Yan², Ding Xue Zhi' ${ }^{2}$ and Long Rui-Jun ${ }^{1}$ \\ ${ }^{1}$ State Key Laboratory of Grassland Agro-Ecosystems, School of Life Sciences, Lanzhou University, Lanzhou, China. \\ ${ }^{2}$ Key Laboratory of Yak Breeding Engineering, Lanzhou Institute of Husbandry and Pharmaceutical Sciences, Chinese Academy of Agricultural Sciences, \\ Lanzhou, China.
}

*Corresponding author: Ding Xuezhi, Key Laboratory of Yak Breeding Engineering, Lanzhou Institute of Husbandry and Pharmaceutical Sciences, 8 Chinese Academy of Agricultural Sciences, Lanzhou 730050, China.

Received Date: March 03, 2020

Published Date: March 06, 2020

\begin{abstract}
Crude oil utilization has improved our living standard, but it has also threatened the aquatic and terrestrial environment with its harmful effects. It contains harmful substances such as polycyclic aromatic hydrocarbons (PAH) that can cause mutation and cancer. Soil contamination is of particular concern as it does not only effects human health but also vegetation growth and biological environment. Many remediation techniques have been devised but a quick, nature friendly and cost-effective method is required to remove and minimize the dangerous effects of crude oil. In this review, different remediation techniques to remove crude oil from the soil have been discussed, focusing on their current advancement. Chemical, physical and thermal methods used for the cleanup of soil have many demerits, so focus is shifted toward biological methods such as microbial remediation and phytoremediation. Recently microbes and plants are used together as rhizoremediation technique to remove contaminants from the soil because of its significant results.
\end{abstract}

Keywords: Crude oil; Polycyclic aromatic hydrocarbons; Bioremediation; Rhizoremediation

\section{Introduction}

Crude oil is a quick and easily accessible source of energy, making our life comfortable and raising the standards of living. It can be found naturally in many parts of the world, particularly in the USA, Russia, Romania, Iran, Mexico, Iraq, Saudi Arabia, Kuwait, Libya, and Nigeria [1]. The petroleum industries generate billion tons of crude oil, natural gas and its derivatives every year. All of these are then undergone further processing for the production of refined products such as diesel, gasoline, petrol and lubricants [2]. It is recorded by international energy agency that demand of oil all over the world in 2015 was 97 million barrels/day which is expected to be 100 million barrels/day up to 2021 [3].

Crude oil is composed of volatile liquid hydrocarbons with varying molecular weight and structure. It contains more than 17,000 hydrocarbons and its classification are based on the most prevalent compound present in it. The three main hydrocarbons components present in crude oil are compiled in Table 1 [4-6].
Table 1: Three main hydrocarbons components present in crude oil.

\begin{tabular}{|c|c|c|}
\hline \multirow{2}{*}{1} & \multirow{4}{*}{ Parrafins } & Methane \\
\cline { 3 - 3 } & & Ethane \\
\cline { 3 - 3 } 2 & \multirow{3}{*}{2} & Octane \\
\hline \multirow{2}{*}{3} & Naphthenes & Benzene \\
\cline { 3 - 3 } & & Toulene \\
\hline \multirow{2}{*}{3} & PAH & Xylene \\
\hline & & Naphthalene \\
\hline & & Anthracene \\
\hline
\end{tabular}

Crude oil contamination is one of the major environmental problems effecting aquatic and terrestrial environments. At present, approximately $80 \%$ of lands are affected by petroleum origin products i.e., hydrocarbons and these products are used in oil and 
chemical industries as energy source [7]. Crude oil makes a covering on the surface of soil and causes the retention of carbon dioxide produced by soil organisms. It also decreases the soil porosity by sticking the soil particles together. The amount of loss depends on the amount and grade of oil spilled [1].

Many accidental spillages of crude oil have threatened the nature. The largest accident in the history of mankind that caused environmental disaster is "Gulf war oil spill" (1991). This accident caused the spill of millions of gallons of crude oil from destroyed oil wells into the water and surrounding land covering 49 square $\mathrm{km}$ of an area [8]. Similarly, "Keystone pipeline accident" (2017) is another disaster of oil spillage. This spill caused the spread of 210,000 gallons of oil on the grass as well as in the agricultural area at southeast of the small town of Amherst in northeast South Dakota [9].

Polycyclic aromatic hydrocarbons (PAH) present in crude oil, declared as primary environmental pollutant by the United States Environmental Protection Agency are mutagenic and carcinogenic [10]. A prolonged contact time of stable PAH with soil stimulate the phenomenon called soil aging, leading to the resistant of soil to any treatment [11]. Leakage of these contaminants from the soil to the ground water can pose risk to human health, vegetation and biological environment [7]. So, it is very important to clean the soil from these harmful substances to guard life from their deadly effects. Besides, by remediating oil contaminated sites more land can be available for residence as well as agricultural activities.

Numerous countries are developing their own strategies to cope with the soil contamination done by crude oil e.g., Lebanon, Kuwait and some other middle east countries have organized oil spill working groups by the aid of environment research organizations for assessment and future remediation of the affected areas [2]. Numerous methods for the removal of crude oil from the contaminated soil have been devised. A quick, nature friendly and cost-effective method is required for this purpose. This review focuses on the current developments of some generally accepted remediation techniques used to treat crude oil contaminated soil.

\section{Chemical Methods}

Chemical oxidation is an efficient method to remove dangerous wastes from the soil at the oil spilled sites. The efficiency of this method strongly depends on the soil matrix. Fenton's reagent, a mixture of Hydrogen peroxide and Ferric ion, is used for chemical oxidation. Hydrogen peroxide is a strong oxidizing agent that generates hydroxyl ions during Fenton's reaction while ferric ion acts as catalyst. Hydroxyl ions are very powerful and effective agents that destroy the contaminants present in the soil $[12,13]$ demonstrated that removal of oil from sand at lower $\mathrm{pH}$ by using Fenton's reagent is much efficient than at natural $\mathrm{pH}$ or peat.

Another efficient oxidant that is used for the removal of crude oil from soil is ozone. It is easy to generate, store and handle for in situ treatment. Polycyclic aromatic hydrocarbons are more reactive with ozone in comparison o alkanes. Reactivity of poly aromatic hydrocarbons depends on the number of rings, heteroatoms presence or absence and alkylation level. Ozone also support microbial community present in the soil as it generates oxygen on its degradation, so it can be helpful in bioremediation method to aid microbial growth [14]. Chemical method is a quick way to treat contaminated soil, but chemicals may pose a serious threat to the nearby soil and living beings due to leaching or side reactions.

\section{Physical Methods}

Excavation of crude oil contaminated soil is the quickest and safe way but not a sophisticated and cheap method. The contaminated soil is removed and transported to appropriate landfill for the disposal. The samples are collected from bottom and sidewalls of the excavated area to check if the site is clean or not [15-17].

Another physical method is the washing of contaminated soil. Washing with organic solvents such as ethanol- water mixture and ethyl acetate-acetone-water mixture exhibited significant removal of hydrocarbons from the contaminated soil [18-20]. Soil washing does not only treat the oil contaminated soil but also remove the heavy metals from the soil. The efficiency of washing can be enhanced by the addition of surfactants. Studies showed that both artificial and natural surfactants are helpful in the removal of crude oil. Different surfactants remove different fractions of crude oil e.g. artificial surfactant sodium dodecyl sulfate (SDS) removed aliphatic hydrocarbons while natural surfactants saponin and rhamnolipid removed polycyclic aromatic hydrocarbons from the contaminated soil [21]. This method no doubt is simple and efficient, however, it is very prolonged, time consuming and very costly. Transportation of contaminated soil to disposal site is another big problem. Surfactants might be dangerous due to their possibility of adhesion to soil particles.

\section{Thermal Methods}

In Thermal stripping/low temperature thermal desorption/soil roasting contaminated soil is heated to very low temperature (200$1000^{\circ} \mathrm{F}$ ) to increase the vaporization and separation of low boiling point contaminants from the soil. By this process organic contaminants can be completely or partially decomposed depending upon the thermal stripping temperature and organic compounds present in the soil. [22]. This method can remove approximately $90 \%$ of the contaminants but it is very costly and not eco-friendly.

Another way to remove crude oil from the soil is incineration. The contaminated soil is burned by using fire at high temperature $\left(1600-2500^{\circ} \mathrm{F}\right)[1]$. This method is also not environmentally friendly as volatile and flammable compounds present in crude oil will cause the environment pollution.

\section{Biological Methods}

Bioremediation is a traditional method that involves the use of living organisms (bacteria, fungi and plants) to degrade harmful 
substances present in the environment. Bioremediation of crude oil from the soil is very efficient, cheap and environmentally friendly solution. The effectiveness of this method is depended on hydrocarbon concentration, soil characteristics and composition of pollutants [8].

PAH are the most resistant and toxic group of soil pollutants present in the crude oil. PAH get trapped in the soil pores after they enter into the soil and retained by the soil matrix. So, their removal from the soil is very difficult [23]. Bioremediation is the most suitable method to remove PAH from the soil as microbes and plant roots can access these tiny pores easily.

\section{Microbe assisted remediation}

Soil is a diverse ecosystem as it inhabits various microbial populations. The composition of naturally residing microbes change Table 2: Bacterial genera degrading three main groups of hydrocarbons. with the composition and concentration of contaminants, so only resistant consortium of microbes survives and work actively in the cleaning of polluted soil [24]. Hydrocarbon degrading microbes are extensively present naturally in the contaminated soil and breakdown complex hydrocarbons into simple form by the use of their enzymatic systems.

Different bacterial genera chose different types of hydrocarbons for the degradation (Table 2) and they can also work in both aerobic and anaerobic condition. In anaerobic condition, bacteria present in the deepest parts of the sediments use nitrates, sulfates and iron as electron acceptor to degrade the hydrocarbons. Some of the species of anaerobic bacteria belonging to genus Desulfococcus, Thauera, Dechloromonas and Azoarcus exhibit hydrocarbon degradation ability [25-26].

\begin{tabular}{|c|c|c|}
\hline Hydrocarbons & Bacterial Genera & References \\
\hline \multirow{7}{*}{ Paraffins } & Acinetobacter & \multirow{7}{*}{ Balba MT et al. [8]; Rojo [15]; Abou-Shanab et al. [67]; De Pasquale et al. [70] } \\
\hline & Flavobacchain & \\
\hline & Gordonia & \\
\hline & Nocardia & \\
\hline & Ochrobactrum & \\
\hline & Pseudomonas & \\
\hline & Sinorhizobium & \\
\hline \multirow{5}{*}{ Naphthene's } & Achromobacter & \multirow{5}{*}{ Di Martino et al. [71]; Ho et al. [73]; Hong et al. [74] } \\
\hline & Acinetobacter & \\
\hline & Bacillus & \\
\hline & Microbacterium & \\
\hline & Pseudomonas & \\
\hline \multirow{12}{*}{$\begin{array}{c}\text { Polycyclic Aromatic Hydrocar- } \\
\text { bons }\end{array}$} & Achromobacter & \multirow{12}{*}{ Ben Said et al. [69]; Wanapaisan et al. [76]; Anwar et al. [68] } \\
\hline & Advenella & \\
\hline & Agrobacterium & \\
\hline & Bacillus & \\
\hline & Mycobacterium & \\
\hline & Novosphingobium & \\
\hline & Ochrobactrum & \\
\hline & Pseudomonas & \\
\hline & Shewanella & \\
\hline & Shigella & \\
\hline & Staphylococcus & \\
\hline & Stenotrophomonas & \\
\hline
\end{tabular}

While in aerobic condition, bacterial dioxygenase enzymes incorporate oxygen into carbon molecule through a series of enzyme catalyzed reactions to generate hydrocarbon with alcohol group. Alcohol groups are oxidized to aldehyde and then converted into carboxylic group by the action of other enzymes which in turn is degraded to acetyl co-A by beta oxidation [27].
The major bacterial genera that showed crude oil degrading capability are Alcaligenes, Sphingomonas, Pseudomonas, Bacillus, Nocardia, Acinetobacter, Micrococcus, Achromobacter, Rhodococcus, Alcaligenes, Moraxella, Mycobacterium, Aeromonas, Xanthomonas, Athrobacter, Flavobacterium, Micrococcus, zospirillum [1, 2,8,2730]. 
Fungal mycelium is very helpful in the degradation of hydrocarbons because of their penetration ability, it also aids in the entrance of bacteria to the deep soil. Fungal laccase, lignin peroxidase and manganese peroxidase enzymes degrade the hydrocarbons by its oxidation [31]. Crude oil degradation has been shown by some members of the following fungal genera: Candida, Stropharia, Rhodotorula, Pleurotus, Penicillium, Phanerochaete, Fusarium [8, 14, 32,27].

Microbial remediation of contaminated soil is affected by many factors such as water amount, temperature and $\mathrm{pH}$ of soil, concentration of oxygen, soil quality and amount of nutrients. Change in any of these factors can decrease the population of microbes and in turn decreases the bioremediation [33].

Microbial activity can be accelerated by using bioaugmentation and bio stimulation strategies. In bioaugmentation exogenous oil degrading bacteria are supplemented to enhance soil microbiota while in bio stimulation addition of nutrients, aeration and optimization of physical conditions like $\mathrm{pH}$ and temperature is performed. Research has shown that bioaugmentation and bio stimulation when used together effectively remediate crude oil hydrocarbons polluted soil. It has been observed that the number of exogenous bacteria decreases after sometimes because of nutrient unavailability or other abiotic factors ( $\mathrm{pH}$, temperature or oxygen). So, bio stimulation incorporation with bioaugmentation provided effective results in the degradation of crude oil pollutants (Figure 1) [1,23,30,34-36]. Different types of surfactants produced by many microorganisms are called biosurfactants. These biosurfactants enhance the bioavailability of hydrocarbons to the microbes and in turn increases its degradation. Use of biosurfactants producing microbes is a good bioremediation choice as this process is cheap, nontoxic with efficient degradation rate. So, researchers have turned their focus towards such microbes that can degrade crude oil and produces biosurfactants at the same time [37].

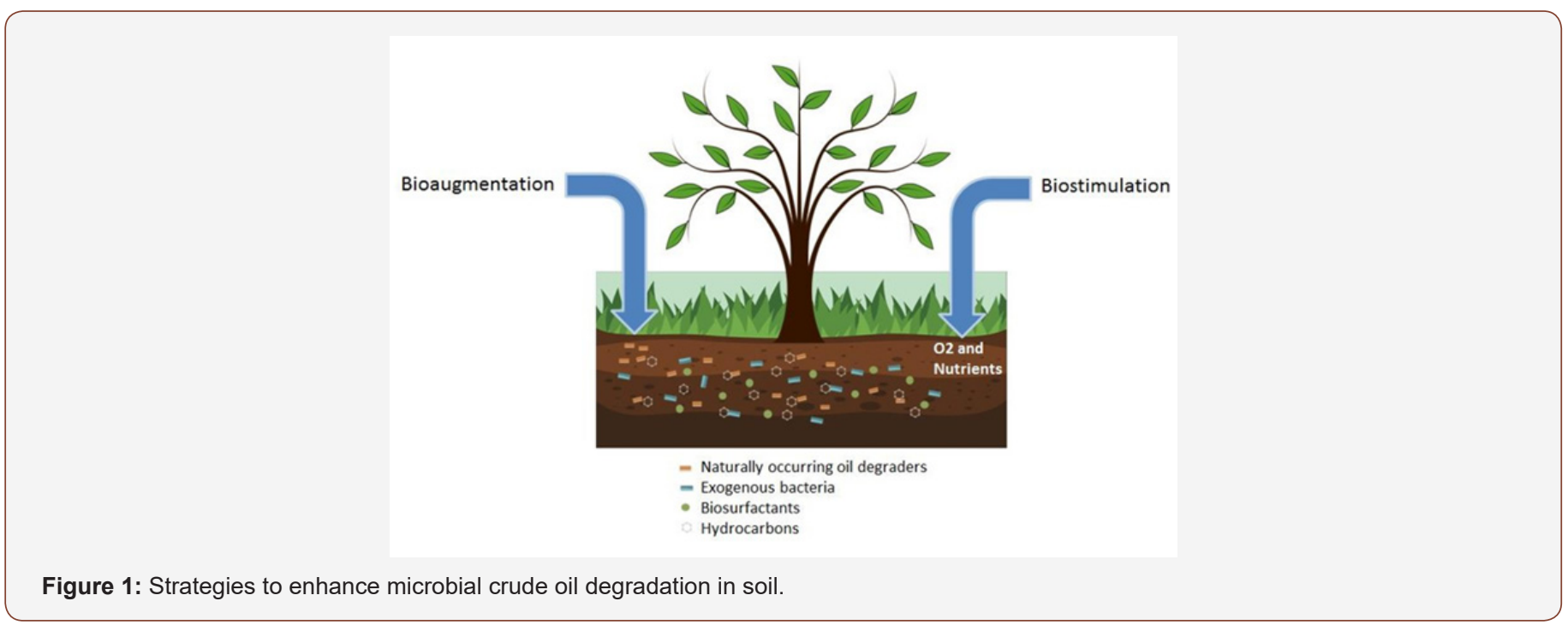

Biosurfactants from Acinetobacter sp., Bacillus subtilis A1, Pseudomonas aeruginosa, Rhodococcus erythropolis M-25, Rhodococcus ruber Em1, Pseudomonas stutzeri have been studied for their role in ioremediation [38-44].

\section{Phytoremediation}

Phytoremediation is an effective, solar driven and low-cost strategy that uses plants for the removal of contaminants from the soil of large contaminated area. Plants have the ability to grow in polluted soil by metabolizing or accumulating the harmful compounds in their roots or shoots [45].

Plants with extended root systems, minimum water requirement, adaptability to a variety of environmental conditions and fast growth rate are appropriate for this purpose [46]. Phytoremediation efficiency depends on the plant species selection, environmental conditions and rhizobacteria [47].

Analysis of soil of the Possession Island after diesel leakage in 1997 showed that area with vegetation has 10\% low concentration of hydrocarbons as compared to non-vegetation area [48].
Different mechanisms are devised by plants for the removal of contaminants i.e., phytoaccumulation (absorption of contaminants into the roots or shoots), phytodegradation (degradation of pollutants by utilization of plant enzymes such as laccase, oxygenase and nitroreductase), phytovolatization (release of volatile metabolites into the atmosphere) and phytostabilization (decrease the movement of contaminants) $[11,49,50]$ reported that two plant species i.e., Eleusine indica and Cynodon dactylon significantly eliminated some low to medium molecular weight PAH from the soil by phytoextraction process, indicating their use in the removal of PAH.

Maize plants showed enhanced biodegradation in association with Cynanchum laeve. This symbiotic relationship between maize roots and Cynanchum laeve degraded 4-6 rings PAH more efficiently than any other treatment [11].

Vetiver grass, belongs to the Poaceae family, is a perennial grass. It decontaminates the soil by extraction of PAH and other toxins from the soil and accumulating it in the roots and shoots. This plant showed negative effect on its growth and other physical activities 
when grown on soil contaminated with diesel [51] Mirabilis jala$p a$ is also considered a good candidate for phytoremediation. [52] investigated that $M$. jalapa can remove $41-63 \%$ of saturated hydro- carbons within 127 days when compared with natural attenuation process (Figure 2).

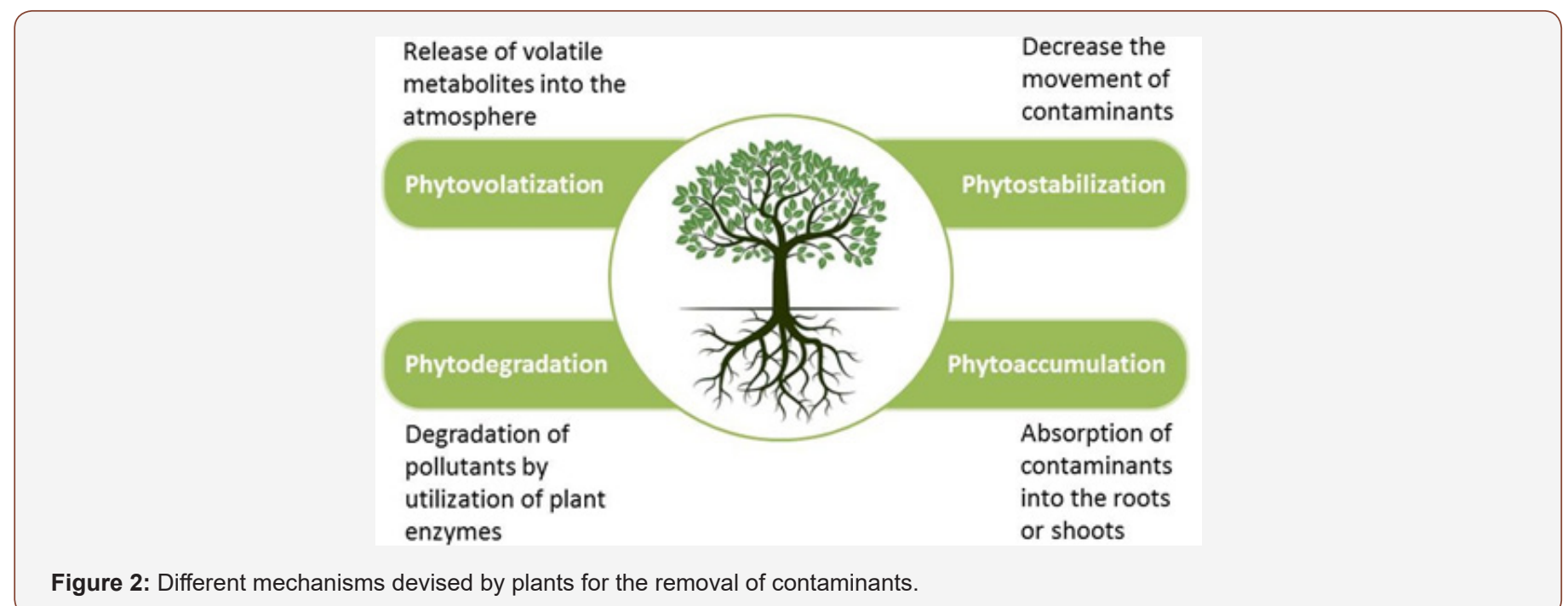

Similarly, ryegrass, alfalfa, tall fescue, prairie grasses, meadow fescue, yellow medick, soybeans, Gazania, Mimosa pudica, Cyperus rotundus have shown good crude oil remediation [53-60].

With all the advantages, phytoremediation also has some drawbacks i.e., it is a time-consuming process, limited remediation in high pollutants concentration and limited area of success [47].

\section{Rhizoremediation (Plant-microbe assisted remedia- tion-recent technology)}

It has been observed that plants efficiency to remediate crude oil enhances in the presence of soil microorganisms. Plants form a synergistic relationship with soil microorganisms in which they provide microbes with space and favorable environment in the rhizosphere region and in turn microbes degrades the contaminants by using their enzyme system. This symbiotic relationship is known as rhizoremediation which is a combination of bioremediation and phytoremediation. Lately, Rhizoremediation is the most successful and cost-effective strategy degrading all types of contaminants present in crude oil. This process occurs naturally, and it can also be stimulated by introducing concerned microbes.

Rhizoremediation requires such plants that can grow in oil contaminated soil and also provide favorable environment to contaminants degrading microbes by exudates secretion or aeration. Plant-microbe strategy not only increases the metabolic activity of rhizosphere microbes, but it also improves the soil physical and chemical properties and increases microbial access to the contaminants present in the soil [56].

PAH degrading bacterial strain Rhodococcus ruber Em1 showed enhanced degradation rate when combined with Orychophragmus violaceus during the period of 175 days in a controlled environment (mesocosms). The expressions of linA and RHD like genes, coding PAH-ring hydroxylating dioxygenase, increase 3-5 times in the mesocosoms [42]. Enhanced degradation of contaminants by maize plant was observed when maize plant was provided with indigenous microbial biomass inoculum [61].

Glycine max (Soybean) plant is among those plants that exhibit hydrocarbon remediating capability. Research showed that soybean remediation of crude oil was not because of the phytoaccumulation but it was a mutual action of G. max and rhizospheric microbes. It was observed that G. max growth in the contaminated soil effect the total number of bacteria, amount of water, $\mathrm{pH}$ and organic matter quantity [62].

A study conducted on wheat plant in hydroponics condition showed that wheat seedlings eliminate more than $20 \%$ of oil from the medium, but this remediating ability enhances to $29 \%$ when grown in association with Azospirillum [63].

Bioremediation of oil contaminated soil by using yellow alfalfa in combination with Acinetobacter sp. strain S- 33 improved the remediation efficiency $39 \%$ in comparison to alone alfalfa (34\%) and Acinetobacter sp. S-33 (35\%). Fractional Contaminants analysis showed that plant microbe association is the most efficient strategy in the cleanup of aromatic hydrocarbons from the soil [63].

Plant growth promoting bacteria (PGPR) promote the tolerance and resistance of plants against contaminants present in the soil. Ryegrass when grown with PGPR showed increased degradation of hydrocarbons to $61.5 \%$ for 3 years when $13 \%$ TPH content was used. It was observed that low concentration enhanced the degradation and vice versa $[3,64]$.

Crude oil after leakage gets trapped or physically bound with the soil particles; access to these micro spaces is made possible by plant roots. Roots of plants harbor microbes in the rhizosphere 
as well as on the surface. So, root generates a pathway for these microbes to have access to these contaminants. Once in the soil micropores, GPR increases the solubility of oil droplets by producing biosurfactants or by adhering to the surface of the oil droplets. Microbial surface membrane oxygenase's than generate fatty acid analogues by adding oxygen atoms into PHC. In this way microbes keep on growing and degrading contaminants. Tentatively, microbes use $150 \mathrm{mg}$ of nitrogen and $30 \mathrm{mg}$ of potassium to degrade $1 \mathrm{~g}$ of PHC [65]. Utilization of plants and microbes in collaboration is indeed a good strategy to recovery contaminated soil. It might be a long process, but it is safer and environment friendly. Further field experiments must be performed to develop good models.

\section{Conclusion}

Crude oil is a quick and easily accessible energy source found in most of the countries. Its leakage during extraction and transportation has posed danger to the environment because it contains mutagenic and carcinogenic compounds. Soil contamination due to crude oil leakage has adverse effects on human and vegetation growth so its removal is essential. Many methods have been developed to remove crude oil from the soil i.e., physical, chemical, thermal and biological. Many alterations and development have been introduced in Physio-chemical and thermal methods to enhance their efficiency and reduce their demerits. Still these methods have many drawbacks and less acceptable by the society. On the other hand, bioremediation methods are preferred because they are efficient, cheap and nature friendly. In the recent technology i.e., rhizoremediation, microbes and plants are combined together in synergistic relationship to efficiently remove the crude oil contaminants from the soil. Research has shown that rhizoremediation is more efficient than microbial and phytoremediation techniques separately.

\section{Future Prospects}

By the advancement in the biotechnology it is possible to enhance the degradation of crude oil contaminants. Genetic engineering can be used to construct such bacterial strains that contain Lin-A and RHD genes translating hydroxylating dioxygenase enzymes that are used to degrade polycyclic hydrocarbons [66-77]. Site directed mutagenesis can be used to modify amino acid sequence of the catalytic domain of related enzymes and enhancing their activity. These enzymes in its purified form can be used to remove contaminants from the soil. By using these techniques care should be given to the process because of the possibility of gene drift into the nature.

\section{Acknowledgment}

This study was supported by the international cooperation and exchange program of the National Natural Science Foundation of China (No. 31461143020) and international cooperation projects in Gansu province (No. 1504WKCA053).

\section{Conflict of Interest}

No conflict of interest.

\section{References}

1. Ezeji U, Anyadoh SO, Ibekwe VI (2007) Cleanup of crude oil-contaminated soil. Terrestrial and Aquatic Environmental Toxicology 1(2): 54-59.

2. Das N, Chandran P (2011) Microbial degradation of petroleum hydrocarbon contaminants: an overview. Biotechnol Res Int 2011: 941810.

3. Dos Santos JJ, Maranho LT (2018) Rhizospheric microorganisms as a solution for the recovery of soils contaminated by petroleum: A review. J Environ Manage 210: 104-113.

4. Germida JJ, Frick CM, Farrell RE (2002) Phytoremediation of oilcontaminated soils. Developments in Soil Science 28: 169-186.

5. Westlake DWS, Jobson A, Phillippe R, Cook FD (1974) Biodegradability and crude oil composition. Can J Microbiol 20(7): 915-928.

6. Pampanin D, Sydnes M (2013) Polycyclic aromatic hydrocarbons a constituent of petroleum: presence and influence in the aquatic environment: Intech Open.

7. Marinescu M, Toti M, Veronica T, Carabulea V, Georgiana P, et al. (2010) An Assessment of the effects of crude oil production on soil properties. Annals: Food Science and Technology, Vol 11.

8. Balba MT, Al Awadhi N, Al Daher R (1998) Bioremediation of oilcontaminated soil: microbiological methods for feasibility assessment and field evaluation. Journal of Microbiological Methods 32(2): 155-164.

9. Smith MBJ (2017) Keystone Pipeline Leaks 210,000 Gallons of Oil in South Dakota. The New York Times.

10. Siles J, Margesin R (2018) Insights into microbial communities mediating the bioremediation of hydrocarbon-contaminated soil from an Alpine former military site. Appl Microbiol Biotechnol 102(10): 4409-4421.

11. Garcia Sánchez M, Košnář Z, Mercl F, Aranda E, Tlustoš P (2017) A comparative study to evaluate natural attenuation, mycoaugmentation, phytoremediation, and microbial-assisted phytoremediation strategies for the bioremediation of an aged PAH-polluted soil. Ecotoxicol Environ Saf 147: 165-174.

12. Kwan W, Voelker B. (2003) Rates of Hydroxyl Radical Generation and Organic Compound Oxidation in Mineral-Catalyzed Fenton-Like Systems. Environ Sci Technol 37(6): 1150-1158.

13. Goi A, Kulik N, Trapido M (2006) Combined chemical and biological treatment of oil contaminated soil. Chemosphere 63(10): 1754-1763.

14. Wang J (2013) Compositional Changes of Hydrocarbons of Residual Oil in Contaminated Soil During Ozonation. Ozone: Science \& Engineering 35(5): 366-374.

15. Ellerman DA, Pei J, Gupta S, Snell WJ, Myles D, et al. (2009) Izumo is part of a multiprotein family whose members form large complexes on mammalian sperm. Mol Reprod Dev 76(12): 1188-1199.

16. Olstein M, Marden DL, Voeller JG, Jennings JD (2005) Succession planning for a vital workforce in the information age: American Water Works Association.

17. Barnes D, Laderach S, Showers C (2002) Treatment of petroleumcontaminated soil in cold, wet, remote regions. Missoula: USDA Forest Service.

18. Khodadoust AP, Suidan MT, Acheson CM, Brenner R C (1999) Solvent extraction of pentachlorophenol from contaminated soils using waterethanol mixtures. Chemosphere 38(11): 2681-2693.

19. Silva A, Delerue Matos C, Fiúza A (2005) Use of solvent extraction to remediate soils contaminated with hydrocarbons. J Hazard Mater 124(1-3): 224-229.

20. Diphare M, Muzenda E (2014) Remediation of oil contaminated soils: A review. In International Conference. On Chemical Integrated Waste Management and Environmental Engineering, Johannesburg, pp. 180184.

21. Urum K, Pekdemir T (2004) Evaluation of biosurfactants for crude oil contaminated soil washing. Chemosphere 57(9): 1139-1150. 
22. Ndimele PE, Saba AO, Ojo DO, Ndimele CC, Anetekhai MA, et al. (2018) Remediation of Crude Oil Spillage. In the Political Ecology of Oil and Gas Activities in the Nigerian Aquatic Ecosystem, pp. 369-384.

23. Safdari MS, Kariminia HR, Rahmati M, Fazlollahi F, Polasko A, et al. (2018) Development of bioreactors for comparative study of natural attenuation, biostimulation, and bioaugmentation of petroleumhydrocarbon contaminated soil. J Hazard Mater 342: 270-278.

24. Zhao X, Fan F, Zhou H, Zhang P, Zhao G (2018) Microbial diversity and activity of an aged soil contaminated by polycyclic aromatic hydrocarbons. Bioprocess and biosystems engineering 41(6): 871-883.

25. Brooijmans RJ, Pastink MI, Siezen RJ (2009) Hydrocarbon-degrading bacteria: the oil-spill clean-up crew. Microb Biotechnol 2(6): 587-594.

26. Rabus R, Boll M, Heider J, Meckenstock R, Buckel W, et al. (2016) Anaerobic Microbial Degradation of Hydrocarbons: From Enzymatic Reactions to the Environment. J Mol Microbiol Biotechnol 26(1-3): 5-28.

27.Xenia M, Refugio R (2016) Microorganisms metabolism during bioremediation of oil contaminated soils. J Bioremed Biodegr 7: 340.

28. Muratova A, Turkovskaya O, P Antonyuk, L, E Makarov O, I Pozdnyakova L, et al. (2005) Oil- oxidizing potential of associative rhizobacteria of the genus Azospirillum. Microbiology 74(2): 210-215.

29. Ghoreishi G, Alemzadeh A, Mojarrad, M, Djavaheri M (2017) Bioremediation capability and characterization of bacteria isolated from petroleum contaminated soils in Iran. Sustainable Environment Research 27(4): 195-202.

30. Roy A, Dutta A, Pal S, Gupta A, Sarkar J, et al. (2018) Biostimulation and bioaugmentation of native microbial community accelerated bioremediation of oil refinery sludge. Bioresour Technol 253: 22-32.

31. Kohlmeier S, Smits TH, Ford RM, Keel C, Harms H, et al. (2005) Taking the fungal highway: mobilization of pollutant-degrading bacteria by fungi. Environ Sci Technol 39(12): 4640-4646.

32. Steffen K, Hatakka A, Hofrichter M (2003) Degradation of Benzo[a] pyrene by the Litter-Decomposing Basidiomycete Stropharia coronilla: Role of Manganese Peroxidase. Appl Environ Microbiol 69(7): 39573964.

33. Yadav BK, Hassanizadeh SM (2011) An Overview of Biodegradation of LNAPLs in Coastal (Semi)-arid Environment. Water Air Soil Pollut 220(1): 225-239.

34. Vogel T (1996) Bioaugmentation as a Soil Bioremediation Approach. Current opinion in biotechnology 7: 311-316.

35. Gentry T, Rensing C, Pepper IAN (2004) New Approaches for Bioaugmentation as a Remediation Technology. Critical Reviews in Environmental Science and Technology 34(5): 447-494.

36. Adams GO, Fufeyin PT, Okoro SE, Ehinomen I (2015) Bioremediation, biostimulation and bioaugmention: a review. International Journal of Environmental Bioremediation \& Biodegradation 3(1): 28-39.

37. Chebbi A, Hentati D, Zaghden H, Baccar N, Rezgui F, et al. (2017) Polycyclic aromatic hydrocarbon degradation and biosurfactant production by a newly isolated Pseudomonas sp. strain from used motor oil-contaminated soil. International Biodeterioration \& Biodegradation 122: $128-140$.

38. Abalos A, Maximo F, Manresa MA, Bastida J (2002) Utilization of response surface methodology to optimize the culture media for the production of rhamnolipids by Pseudomonas aeruginosa AT10. Journal of Chemical Technology \& Biotechnology 77(7): 777-784.

39. Rahman P, Rahman T, Mc Clean S, Marchant R, Banat I (2002) Rhamnolipid Biosurfactant Production by Strains of Pseudomonas aeruginosa Using Low-Cost Raw Materials. Biotechnol Prog 18(6): 1277-1281.

40. Pi Y, Chen B, Bao MT, Fan F, Cai Q, Ze L (2017) Microbial degradation of four crude oil by biosurfactant producing strain Rhodococcus sp. Bioresource technology 232: 263-269.
41. Parthipan P, Preetham E, Machuca LL, Rahman PK, Murugan K, et al. (2017) Biosurfactant and Degradative Enzymes Mediated Crude Oil Degradation by Bacterium Bacillus subtilis A1. Front Microbiol 8: 193.

42. Kong F, Sun Gd, Liu Zp (2018) Degradation of polycyclic aromatic hydrocarbons in soil mesocosms by microbial/plant bioaugmentation: Performance and mechanism. Chemosphere 198: 83-91.

43. Yalaoui Guellal D, Brahmi F, Touati A, De Champs C, Banat I, et al. (2017) Production of Biosurfactants by Hydrocarbons degrading bacteria isolated from Soummam watershed Sediments of Bejaia in Algeria. Environmental Progress \& Sustainable Energy 37(1): 189-195.

44. Haritash A, Kaushik C (2009) Biodegradation aspects of polycyclic aromatic hydrocarbons (PAHs): a review. J Hazard Mater 169(1-3): 1-15.

45. De Boer J, Wagelmans M (2016) Polycyclic aromatic hydrocarbons in soil-practical options for remediation. CLEAN-Soil, Air, Water 44(6): 648-653.

46. Escobar Alvarado LF, Vaca Mier M, Lopez R, Rojas Valencia MN (2018) Hydrocarbon Degradation and Lead Solubility in a Soil Polluted with Lead and Used Motor Oil Treated by Composting and Phytoremediation. Bull Environ Contam Toxicol 100(2): 280-285.

47. Farraji H, Zaman N, Tajuddin R, Faraji H (2016) Advantages and disadvantages of phytoremediation A concise review. International journal of environment and technology 2: 69-75.

48. Errington I, King CK, Wilkins D, Spedding T, Hose GC (2018) Ecosystem effects and the management of petroleum-contaminated soils on subantarctic islands. Chemosphere 194: 200-210.

49. Alagić SČ, Maluckov BS, Radojičić VB (2014) How can plants manage polycyclic aromatic hydrocarbons? May these effects represent a useful tool for an effective soil remediation? A review. Clean Technologies and Environmental Policy 17(3): 597-614.

50. Nguemté PM, Wafo GD, Djocgoue P, Noumsi IK, Ngnien, AW (2018) Potentialities of six plant species on phytoremediation attempts of fuel oil-contaminated soils. Water, Air, \& Soil Pollution 229(3): 88.

51. Dudai N, Tsion I, Shamir SZ, Nitzan N, Chaimovitsh D, et al. (2018) Agronomic and economic evaluation of Vetiver grass (Vetiveria zizanioides L.) as means for phytoremediation of diesel polluted soils in Israel. J Environ Manage 211: 247-255.

52. Peng S, Zhou Q Cai Z, Zhang Z (2009) Phytoremediation of petroleum contaminated soils by Mirabilis Jalapa L. in a greenhouse plot experiment. Journal of hazardous materials 168(2-3): 1490-1496.

53. Tang J, G Wang R, W Niu X, MW, R. Chu H, Zhou Q (2010) Characterisation of the rhizoremediation of petroleum-contaminated soil: Effect of different influencing factors. Biogeosciences 7(12): 3961-3969.

54. Soleimani M, Majid A, Hajabbasi M, Nourbakhsh F, Sabzalian M, Christensen J (2010) Phytoremediation of an Aged Petroleum Contaminated Soil Using Endophyte Infected and Non- Infected Grasses. Chemosphere 81(9): 1084-1090.

55. Basumatary B, Saikia R, Bordoloi S (2012) Phytoremediation of crude oil contaminated soil using nut grass, Cyperus rotundus. J Environ Biol 33(5): 891-896.

56. Kuiper I, Lagendijk E, Bloemberg G, Lugtenberg B (2004) Rhizoremediation: A Beneficial Plant-Microbe Interaction. Mol Plant Microbe Interact 17(1): 6-15.

57. Budhadev B, Rubul S, Sabitry B, Hari SP (2014) Phytoremediation of Petroleum Hydrocarbon (PHC) Contaminated Soil by Using Mimosa pudica LJ Environ Sci Eng 56(3): 327-332.

58. Anikwe M, Ikenganyia E, Egbonimale J, Oputah C (2017) Assessment of Some Tropical Plants for Use in the Phytoremediation of Petroleum Contaminated Soil: Effects of Remediation on Soil Physical and Chemical Properties. International Journal of Plant \& Soil Science 14(2): 1-9. 
59. Ikeura H, Kawasaki Y, Kaimi E, Nishiwaki J, Noborio K, et al. (2016) Screening of plants for phytoremediation of oil-contaminated soil. Int J Phytoremediation 18(5): 460-466.

60. Panchenko L, Muratova A, Turkovskaya O (2016) Comparison of the phytoremediation potentials of Medicago falcata L. And Medicago sativa L. in aged oil-sludge-contaminated soil. Environ Sci Pollut Res Int 24(3): 3117-3130.

61. Segura A, Luis Ramos J (2012) Plant-bacteria interactions in the removal of pollutants. Current opinion in biotechnology 24(3): 467-473.

62. Njoku K, Akinola M, Oboh B (2016) Phytoremediation of Crude Oil Contaminated Soil Using Glycine max (Merril); Through Phytoaccumulation or Rhizosphere Effect? Journal of Biological \& Environmental Sciences 10(30): 115-124.

63. Muratova A, V Panchenko L, V Semina D, Golubev S, Turkovskaya 0 (2018) New strains of oil- degrading microorganisms for treating contaminated soils and wastes. In IOP Conference Series: Earth and Environmental Science 107: 012-066.

64. Huang XD, El Alawi Y, Gurska J, Glick B, M Greenberg B (2005) A MultiProcess Phytoremediation System for Decontamination of Persistent Total Petroleum Hydrocarbons (TPHs) from Soils. Microchemical Journal 81(1): 139-147.

65. Gerhardt K, Huang XD, Glick B, M Greenberg B (2009) Phytoremediation and rhizoremediation of organic soil contaminants: Potential and challenges. Plant science 176(1): 20-30.

66. Kulshreshtha S (2013) Genetically Engineered Microorganisms: A Problem-Solving Approach for Bioremediation. Journal of Bioremediation and Biodegradation 4(4): 1-2.

67. Abou Shanab RA, Eraky M, Haddad AM, Abdel Gaffar ARB, Salem AM (2016) Characterization of crude oil degrading bacteria isolated from contaminated soils surrounding gas stations. Bull Environ Contam Toxicol 97(5): 684-688.

68. Anwar Y, El Hanafy AA, Sabir JSM, Al Garni SMS, Al Ghamdi K, et al. (2017) Characterization of Mesophilic Bacteria Degrading Crude Oil from Different Sites of Aramco, Saudi Arabia. Polycyclic Aromatic Compounds, pp. 1-9.

69. Ben Said O, Goñi Urriza M, El Bour M, Dellali M, Aissa P, et al. (2008) Characterization of aerobic polycyclic aromatic hydrocarbon-degrading bacteria from Bizerte lagoon sediments, Tunisia. J Appl Microbiol 104(4): 987-997.

70. De Pasquale C, Palazzolo E, Lo Piccolo L, Quatrini P (2012) Degradation of long-chain n-alkanes in soil microcosms by two actinobacteria. J Environ Sci Health A Tox Hazard Subst Environ Eng 47(3): 374- 381.

71. Di Martino C, López NI, Raiger Iustman LJ (2012) Isolation and characterization of benzene, toluene and xylene degrading Pseudomonas sp. selected as candidates for bioremediation. International Biodeterioration \& Biodegradation 67: 15-20.

72. M Huang, JM Bollag L Gianfreda (Eds.), Developments in Soil Science 28: 169-186.

73. Ho YN, Mathew DC, Hsiao SC, Shih CH, Chien MF, et al. (2012) Selection and application of endophytic bacterium Achromobacter xylosoxidans strain F3B for improving phytoremediation of phenolic pollutants. J Hazard Mater 219-220: 43-49.

74. Hong YH, Ye CC, Zhou QZ, Wu XY, Yuan JP, et al. (2017) Genome Sequencing Reveals the Potential of Achromobacter sp. HZ01 for Bioremediation. Front Microbiol 8: 1507.

75. Rojo F (2009) Degradation of alkanes by bacteria: Minireview Vol. 11.

76. Wanapaisan P, Laothamteep N, Vejarano F, Chakraborty J, Shintani M, et al. (2017) Synergistic degradation of pyrene by five culturable bacteria in a mangrove sediment-derived bacterial consortium, Vol. 342.

77. Wang C, Sun H, Liu H, Wang B (2014) Biodegradation of pyrene by Phanerochaete chrysosporium and enzyme activities in soils: Effect of SOM, sterilization and aging. Journal of Environmental Sciences 26(5): 1135-1144 